\title{
Effect of a fatty acid supplement on the estrus cycle and pregnancy rates of Brazilian Pony mares
}

\author{
Maria C. H. B. Canibal', Adriana P. Neves', Fabiana S. Castro', Joana W. Gregory', Gustavo Rupp Larentis ', Christina R. Trein ', \\ Ricardo M. Gregory and Rodrigo C. Mattos ${ }^{1,2}$
}

REPROLAB, Departamento de Medicina Animal, FAVET-UFRGS ${ }^{1}$ and Cnpq Research Fellowship ${ }^{2}$ Porto Alegre, Brazil

\begin{abstract}
Summary
The objective of this trial was to investigate the effect of a supplement rich in long-chain fatty acids on the reproductive performance in order to anticipate the onset of the cyclic season of mares. Twenty adult anestrous Brazilian pony mares aged between 4 and 10 years were used. Mares were examined for reproductive soundness and divided in two groups of ten mares with similar body condition (BC) in August. Group 1 received $50 \mathrm{~mL}$ of a rice oil commercial supplement, rich in gamma-oryzanol, oleic and linoleic acid, and group 2 (control) received $100 \mathrm{~g}$ sucrose diluted in $100 \mathrm{~mL}$ water. Both treatments resulted in $400 \mathrm{kcal}$ daily. The mares were examined daily by rectal palpation and ultrasonography. Mares in estrous and with a dominant follicle (> $30 \mathrm{~mm}$ ) were bred with a stallion of proven fertility every other day until ovulation (day 0). Reproductive tract examinations restarted on day 6 post-ovulation until the day an embryonic vesicle was detected and from this day on until day 60 of pregnancy. BC was evaluated again in November and in January. Analyzed parameters were: number of days from the beginning of the treatments to the first ovulation of the season (T-Ov); diameter of the first ovulatory follicle of the season $(\mathrm{mm})$, diameter $(\mathrm{mm})$ and area $(\mathrm{cm} 2)$ on day 0 of the corpus hemorrhagicum $(\mathrm{CH})$ and on day 6 of the corpus luteum $(\mathrm{CL})$, circulating progesterone $(\mathrm{ng} / \mathrm{dl})$, percentage of mares cycling in January, pregnancy rates, and BC. No differences were observed among treatments in T-Ov $(P=0.37)$, diameter of the first ovulatory follicle of the season $(P=0.19), C H$ diameter $(P=0.23), C H$ area $(P=0.11)$, $C L$ diameter $(P=0.19), C L$ area $(P=0.70)$, circulating progesterone $(P=0.31)$, percentage of mares cycling $(P=0.47)$ and pregnancy rates $(P=0,76)$. It was concluded that a rice oil supplement was not effective to anticipate the onset of the cyclic season.
\end{abstract}

Keywords: miniature mares; body condition; reproduction; fertility

\section{Auswirkung einer Supplementierung mit langkettigen Fettsäuren auf den Zyklus und der Trächtigkeitsrate von Stuten der Rasse Pony Brasiliero}

Ziel dieser Arbeit war herauszufinden, welche Auswirkung die Supplementierung mit langkettigen Fettsäuren auf die Fruchtbarkeit von Ponystuten hat, insbesondere um den Beginn des Zyklus in der Decksaison vorzuziehen. Es wurden zwanzig erwachsene Stuten der Rasse "Brasilianisches Pony" im Alter zwischen vier und zehn Jahren in den Versuch aufgenommen. Die Stuten wurden auf Weiden gehalten und erhielten zusätzlich zwei Mal täglich Heu und Futterkonzentrat, um einen ausgewogenen Bedarf an Energie, Proteinen und Mikronährstoffen zu decken. Trinkwasser und Zusätze an Mineralien standen den Tieren nach Belieben zur Verfügung. Im August wurden die Stuten auf ihre Fruchtbarkeit untersucht und in zwei Gruppen von je zehn Tieren mit vergleichbarem körperlichen Allgemeinzustand unterteilt. Die Stuten der Gruppe 1 erhielten einen Zusatz von $50 \mathrm{ml}$ eines handelsüblichen Reisöls, reich an Gamma-oryzanol und Linolsäure, die Tiere der Gruppe 2 (Kontrollgruppe) bekamen $100 \mathrm{~g}$ Saccharose, gelöst in $100 \mathrm{ml}$ Wasser. In beiden Behandlungsgruppen wurden den Tieren $400 \mathrm{kcal}$ zugeführt. Es wurden nur Stuten in einer klinisch guten Körperkondition (body condition - BC) eingesetzt. Die Tiere wurden täglich rektal und mit Ultraschall untersucht. Rossige Stuten mit einem "dominanten" Follikel (>30mm) wurden alle 48 Stunden bis zur Ovulation (Tag 0) von einem Hengst mit nachgewiesener Fertilität gedeckt. Sechs Tage nach der Ovulation bis zur Bestimmung der embryonalen Blase wurden die gynäkologischen Untersuchungen erneut aufgenommen. Von diesem Zeitpunkt an folgten Untersuchungen bis zum sechzigsten Tag der Trächtigkeit. Im November und Januar wurde der BC nochmals bewertet. Dabei wurden folgende Parameter erfasst: der Zeitraum zwischen dem Beginn der zusätzlichen Ernährung bis zur ersten Ovulation der Saison (E-Ov), Durchmesser (mm) der ersten Follikel der Saison, Durchmesser (mm) und Fläche des "corpus haemorrhagicum" am Tag O (CLA) und Durchmesser (mm), Fläche des "corpus luteum" am sechsten Tag (CL) und zirkulierende Progesterone. Weiterhin wurden die Anzahl der im Januar rossenden Stuten, die Trächtigkeitsrate und der BC bewertet. Zwischen den beiden Gruppen wurden keine Unterschiede hinsichtlich der ersten Ovulation der Saison $(p=0,37)$, des Durchmessers der ersten Follikel $(p=0,19)$, des Durchmessers des Corpus luteums $(p=0,23)$, der Fläche des Corpus luteum $(p=0,11)$, des Durchmessers der corpora lutea am sechsten $(p=0,19)$, der Fläche der Corpora lutea am sechsten Tag ( $p=0,70)$, der zirkulierender Progesterone $(p=0,31)$, des Prozentsatzes an rossenden Stuten $(p=0,47)$ und der Trächtigkeitsrate $(p=0,76)$ festgestellt. Daraus lässt sich schliessen, dass sich der Zyklus in der Decksaison durch die Zugabe von Reisöl nicht vorziehen lässt.

Schlüsselworter: Ponystuten, Körperkondition, Reproduktion, Fertilität

\section{Introduction}

Nowadays, the use of many miniature horse breeds is becoming more popular. In Brazil, they include the Brazilian Pony Breed which originates from a cross of Shetland and the Fallabela, and the more recently introduced American Miniature Horse (Bergmann et al. 1997).
Several studies in cattle and other mammals show that feeding or infusing different types of fat with varying polyunsaturated fatty acids (PUFA) content to females can alter: the number and size of ovarian follicles, the ovulation rate, progesterone production by the corpus luteum, the timing of luteolysis and gestational length. (Abayasekara and Wathes 1999). Previous reports also concluded that fat supplementa- 
tion in cows under low-energy dietary levels can enhance LH levels (Hightstoe et al. 1991). In horses of any size, little is known about the influence of PUFA supplementation on their reproductive performance in order to anticipate the onset of the cyclic season. In cows, the addition of long-chain fatty acids interferes on prostaglandin release (Oldick et al. 1997). The aim of this study was to investigate if a supplement rich in long-chain fatty acids can anticipate the onset of the cyclic season in non-cycling miniature mares.

\section{Materials and methods}

Twenty adult anoestrous Brazilian pony mares aged between 4 and 10 years were used. Mares were grazed on pasture and fed with hay and with a concentrated ration balanced to provide their daily requirements for energy, protein and micro-nutrients, twice a day. Water and mineral supplementation were freely available. Mares were examined for reproductive soundness and divided in two groups of ten mares with similar body condition (BC) in August. Group 1 received $50 \mathrm{~mL}$ from a commercial supplement of rice oil ${ }^{1}$, rich in gamma-oryzanol, oleic and linoleic acid, and group 2 (control), received $100 \mathrm{~g}$ sucrose diluted in $100 \mathrm{~mL}$ water. Both treatments resulted in $400 \mathrm{kcal}$ daily. Only clinically normal mares were used. The mares were examined daily by rectal palpation and ultrasonography. Mares in estrous and with a dominant follicle (> $30 \mathrm{~mm}$ ) were bred with a stallion of proven fertility and this procedure was repeated every other day until ovulation (day 0). After ovulation, reproductive tract examinations restarted on day 6 post-ovulation until the day an embryonic vesicle was detected and from this day on until day 60 of pregnancy. BC was evaluated again in November and in January. Analyzed parameters were: number of days from the beginning of the treatments to the first ovulation in the season (T-Ov); diameter of the first ovulatory follicle of the season $(\mathrm{mm})$, diameter $(\mathrm{mm})$ and area on day 0 of the corpus hemorrhagicum $(\mathrm{CH})$ and on day 6 of the corpus luteum $(\mathrm{CL})$, circulating progesterone $(\mathrm{ng} / \mathrm{dl})$, percentage of mares cycling in January, pregnancy rates, and BC. The results were compared between groups with the Chi - Square Test and ANOVA.

\section{Results}

The $\mathrm{BC}$ of the miniponies in all evaluations performed did not differ $(P<0.05)$ between the two experimental groups and increased during the study.

No differences were observed among treatments in T-Ov $(P$ $=0.37)$, diameter of the first ovulatory follicle of the season $(P=0.19), C H$ diameter $(P=0.23), C H$ area $(P=0.11)$, $C L$ diameter $(P=0.19), C L$ area $(P=0.70)$, circulating progesterone $(P=0.31)$, percentage of mares cycling $(P=$ $0.47)$ and pregnancy rates $(P=0.76)$. Comparison of the parameters day to first ovulation, $\mathrm{CL}$ diameter and area are shown on Table 1.

The comparison of the percentage of the mares cycling in January and the pregnancy rates between groups are shown on Table 2. One mare from the control group had an early embryonic death.
Table 1 Comparison on days to first ovulation in breeding season, diameter of the first ovulatory follicle, diameter and area of $\mathrm{CH}$, diameter and area of $\mathrm{CL}$ and circulating progesterone in miniature mares treated with rice oil and control.

Vergleich zwischen Ponystuten, die mit Reisöl gefüttert wurden, und Kontrollstuten: Tag der ersten Ovulation der Zuchtsaison, Durchmesser des ersten ovulatorischen Follikel, Durchmesser und Fläche des Corpus haemorrhagicum (CH), Durchmesser und Fläche des Corpus luteum (CL) und zirkulierende Progesteronwerte.

\begin{tabular}{lcc}
\hline & Rice Oil & Control \\
\hline $1^{\text {st }}$ ovulation (no. of days) & $72.77 \pm 23.55$ & $61.42 \pm 24.81$ \\
Follicle diameter $(\mathrm{mm})$ & $34.2 \pm 3.4$ & $37.0 \pm 4.7$ \\
$\mathrm{CH}$ diammeter $(\mathrm{mm})$ & $19.2 \pm 3.8$ & $21.6 \pm 3.9$ \\
$\mathrm{CH}$ área $\left(\mathrm{cm}^{2}\right)$ & $2.3 \pm 0.9$ & $3.6 \pm 2.1$ \\
$\mathrm{CL}$ diameter $(\mathrm{mm})$ & $19.1 \pm 3.77$ & $21.57 \pm 3.9$ \\
$\mathrm{CL}$ area $\left(\mathrm{cm}^{2}\right)$ & $2.33 \pm 0.91$ & $3.62 \pm 2.08$ \\
$\mathrm{Circulating}$ Progesterone & $13.9 \pm 1.6$ & $17.7 \pm 3.1$ \\
\hline
\end{tabular}

Table 2 Comparison between groups on number of mares cycling and number of pregnant mares in miniature mares treated with rice oil and control.

Vergleich zwischen Ponystuten, die mit Reisöl gefüttert wurden, und Kontrollstuten: Anzahl der zyklierenden und der trächtigen Stuten.

\begin{tabular}{|c|c|c|}
\hline & Rice Oil & Control \\
\hline No. of mares cycling & $9 / 10$ & $7 / 9$ \\
\hline Pregnant mares & $6 / 10$ & $6 / 9$ \\
\hline
\end{tabular}

\section{Discussion}

Several studies in cattle and other mammals show that feeding females with fat rich in PUFA can alter the size of ovarian follicles and progesterone production by the corpus luteum (Abayasekara and Wathes 1999) and enhance LH levels in cows under low-energy dietary intake (Hightstoe et al. 1991). The administration of PUFA appeared also to enhance ovulation in rats (Trujillo and Broughton 1995). This effect may be induced by changes in the prostaglandin E3:E2 ratio and the synthesis of less biologically active prostaglandin E3, or by dilution of the anti-ovulatory properties attributable to prostaglandin E2. Cows fed with a rich omega-3 diet had their levels of PGF2 $\alpha$ decreased (Petit et al. 2002), which could contribute to improve fertility through a reduced luteolysis (Thatcher et al. 1995). These cows showed also a tendency to have a greater size of the dominant follicle; probably due to the influence of the fatty acids on cholesterol blood levels (Petit et al. 2002). Fatty acids had an influence on the size of corpus luteum, which was found to be greater in cows that received great dietary amounts of Omega-3 (Petit et al. 2002). Mattos et al. (2004), feeding postpartum cows with a fish oil supplementation, found that the cows had reduced plasma concentrations of PGFM in the early postpartum period, which could prevent an early corpus luteum regression.

However, no effect was observed on advancing the beginning of the cyclic season, on the size of the first ovulatory follicle of the season, on the size of $C L$ and on circulating progesterone when miniature mares were supplemented with fatty acids. 
The lack of any of these effects in miniature mares may be due to a series of factors. One of them is that a subdosis may have been proposed, and that for horses it may be needed some greater amount of omega-3 to achieve any affect. It may also be that unknown individual breed metabolism factors might have influenced.

Body condition is an important factor affecting the onset of cyclicity in postpartum mares (Nagy et al. 1998), as well as in non-lactating mares in the beginning of the breeding season. It is known that in mares, reproductive response to a photoperiod increase is modified by energy availability, which may be signaled to the hypothalamus-pituitary axis by a change in the levels of leptin (Fitzgerald and McManus 2000, Ferreira-Dias et al. 2005). The lack of effect of the supplement could be due to the fact that the mares of both groups treated improved their body condition during the study due to the energy intake and not to the fatty acids.

It was concluded that a rice oil supplement was not effective to anticipate the onset of the cyclic season. Further studies with different PUFA doses are required to verify a possible beneficial effect on reproductive parameters in mares.

\section{Manufacturer's address}

1 Gama-Horse- Helmut Tessmann Ind. E Com. De Óleos Vegetais Ltda. - Rod. BR-116 km 388 - Camaquã- RS Brazil

\section{References}

Abayasekara D. R. and D. C. Wathes (1999) Effects of altering dietary fatty acid composition on prostaglandin synthesis and fertility. Prostaglandins Leukot Essent. Fatty Acids 61, 275-287

Bergmann J. A. G., M. D. Costa, G. B. Mourão and M. Houri Neto (1997) Formação e estrutura da raça pônei Brasileira. Arq. Bras. Med. Vet. Zootec. 49, 251-259

Ferreira-Dias G. M. L., F. Claudino, H. Carvalho, R. Agrícola, J. Alpoim-Moreira and J. Robalo Silva (2005) Seasonal reproduction in the mare: possible role of plasma leptin, body weight and immune status. Domestic Animal Endocrinology 29, 203-213
Fitzgerald B. P. and C. J. McManus (2000): Photoperiod versus metabolic signals as determinants of seasonal anestrus in the mare. Biol. Reprod. 63, 335-340

Hightshoe R. B., R. C. Cochran, L. R. Corah, G. H. Kiracofe, D. L. Harmon and R. C. Perry (1991) Effects of calcium soaps of fatty acids on post-partum reproduction in beef cows. Journal of Animal Science 69, 4097-4103

Mattos R., C. R. Staples, A. Arteche, M. C. Wiltbank, J. Diaz, T. C. Jenkins and W. W. Thatcher (2004): the effects of feeding fish oil on uterine secretion of PGF2 $\alpha$, milk composition, and metabolic status of periparturient Holstein cows. Journal of Dairy Science 87, 921-932

Nagy P., G. Huzsenicza, J. Juhász, M. Kulcsár, L. Solti, J. Reicziegel and K. Abaváry (1998) Factors influencing ovarian activity and sexual behavior of postpartum mares under farm conditions. Theriogenology 50, $1109-1120$

Oldick B. S., C. R. Staples, W. W. Thatcher and P. Gyawu (1997) Abomasal infusion of glucose and fat - effects on digestion, production, and ovarian and uterine functions of cows. Journal of Dairy Science 80, 1315-1328

Petit A. V., R. J. Dewhurst, J. G. Proulx, M. Khalid, W. Haresign and $H$. Twagiramungu (2002) Milk production, milk composition, and reproductive function of dairy cows fed different fats. Canadian Journal of Animal Science 81, 263-271

Thatcher W. W., M. D. Meyer and G. Danet-Desnoyers (1995): Maternal recognition of pregnancy. Journal of Reproduction and Fertility, Suppl. 49, 15-28

Trujillo E. P. and K. S. Broughton (1995): Ingestion of n-3 polynsatured fatty acids and ovulation in rats. Journal of Reproduction and Fertility 105, 197-203
M. C. H. B. Canibal

REPROLAB

Departamento de Medicina Animal

FAVET-UFRGS

Av. Bento Gonçalves 9090

91540-000 Porto Alegre-RS

Brazil

rcmattos@ufrgs.br

\title{
Pferdeheilkunde Curriculum
}

Röntgen I - Kopf, Hals und Vordergliedmaße Hartmut Gerhards und Martin Philipp

15.-16. März 2008

Berlin-Brandenburgische Akademie der Wissenschaften

\section{Röntgen-Aktualisierungskurs}

\author{
Beate Münzer \\ 14.-15. März 2008 \\ www.curricula.cc
}

